(c) American Dairy Science Association, 2006.

\title{
Effect of Prepartum Dietary Calcium on Intake and Serum and Urinary Mineral Concentrations of Cows
}

\author{
P. S. Chan, J. W. West, ${ }^{1}$ and J. K. Bernard \\ Department of Animal and Dairy Science, University of Georgia Coastal Plain Experiment Station, \\ Tifton 31793-0748
}

\begin{abstract}
Nine multiparous and 12 primiparous cows were fed diets containing an anionic salt supplement and moderate $\mathrm{Ca}(0.99 \%)$ or high $\mathrm{Ca}(1.50 \%)$ concentrations for $21 \mathrm{~d}$ prepartum to determine the effects of dietary $\mathrm{Ca}$ concentration on serum and urine electrolytes and on postpartum intake and milk yield. Blood samples were collected during 21 to $1 \mathrm{~d}$ prepartum, 0 to $2 \mathrm{~d}$ postpartum, and 3 to $21 \mathrm{~d}$ postpartum. Dietary cation-anion difference (DCAD) for prepartum diets was approximately -6 $\mathrm{mEq} / 100 \mathrm{~g}$ of dry matter $(\mathrm{Na}+\mathrm{K}-\mathrm{Cl}-\mathrm{S})$. Immediately postpartum, cows were fed diets with positive DCAD with greater than $1.00 \%$ Ca concentration. Mean serum Ca concentrations 21 to $1 \mathrm{~d}$ prepartum, 0 to $2 \mathrm{~d}$ postpartum, and 3 to $21 \mathrm{~d}$ postpartum were $9.62,8.41$, and 9.38 $\mathrm{mg} / \mathrm{dL}$. There were no treatment effects on serum Ca concentration. Mean serum Ca concentration was higher for primiparous than multiparous cows (9.34 vs. 8.93 $\mathrm{mg} / \mathrm{dL}$ ) for the trial and at calving ( $8.77 \mathrm{vs.} 8.13 \mathrm{mg} / \mathrm{dL})$. Mean serum $\mathrm{HCO}_{3}{ }^{-}$and urinary $\mathrm{pH}$, respectively, were $20.32 \mathrm{mEq} / \mathrm{L}$ and 5.67 prepartum, $25.82 \mathrm{mEq} / \mathrm{L}$ and 7.62 at calving, and $26.08 \mathrm{mEq} / \mathrm{L}$ and 8.25 postpartum. No differences due to treatment were observed for serum and urinary concentrations of $\mathrm{HCO}_{3}^{-}, \mathrm{pH}, \mathrm{Mg}, \mathrm{Na}, \mathrm{K}$, and $\mathrm{Cl}$. Milk yield was similar for 0.99 and $1.50 \% \mathrm{Ca}$ treatments $(22.8$ and $20.7 \mathrm{~kg} / \mathrm{d})$. Diets containing 0.99 or $1.5 \% \mathrm{Ca}$ maintained serum $\mathrm{Ca}$ at adequate levels around parturition and resulted in similar dry matter intake and postpartum milk yield.
\end{abstract}

Key words: hypocalcemia, dietary cation-anion difference, transition period

\section{INTRODUCTION}

Clinical hypocalcemia (milk fever) often occurs within 24 to $48 \mathrm{~h}$ of parturition and is due to the inability of the cow to meet the sudden physiological demand for $\mathrm{Ca}$ at calving. Milk fever is estimated to cost $\$ 334$ per

Received February 18, 2005.

Accepted October 5, 2005.

${ }^{1}$ Corresponding author: joewest@uga.edu incident (Guard, 1996) and shortens the productive life of the dairy cow by $3.4 \mathrm{yr}$ (Payne, 1968). Hypocalcemia also increases the risk of other diseases including retained placenta, displaced abomasum, metritis, mastitis, and ketosis (Curtis et al., 1983). Originally, high dietary Ca content prepartum was hypothesized to cause milk fever and diets low in Ca were fed prepartum to prevent milk fever (Goings et al., 1974). Low dietary Ca initiated the cascade of events leading to parathyroid hormone (PTH) stimulation, bone Ca mobilization, and greater plasma Ca concentration. However, feeding low dietary Ca prepartum for the prevention of milk fever is often challenging when formulating rations and limits the use of legumes and other high $\mathrm{Ca}$ feeds for nonlactating, pregnant dairy cows.

Research with prepartum cows indicates that dietary alkalinity, rather than $\mathrm{Ca}$ concentration, causes milk fever (Goff and Horst, 1997). Reducing DCAD by increasing dietary acidity or employing anionic salts has been efficacious and cost effective in the prophylaxis of milk fever. Block (1984) reported no milk fever cases when feeding an anionic diet compared with a $47 \%$ incidence of milk fever for a cationic diet. Reduced incidence of milk fever with anionic diets has been reported in several studies (Block, 1984; Oetzel et al., 1988; Moore et al., 2000).

High concentrations of dietary anionic salts cause an influx of negatively charged ions systemically, leading to increased hydrogen ion concentration to maintain electroneutrality. Increased hydrogen ion concentration induces a mild metabolic acidosis (Vagg and Payne, 1970). Dietary acidity is believed to increase systemic acidity that increases bone resorption (Block, 1984) as a compensatory mechanism to mobilize bicarbonate and carbonate from skeletal reserves for blood buffering. Acidogenic diets are hypothesized to increase plasma 1,25dihydroxycholecalciferol (Goff et al., 1991) and blood ionized $\mathrm{Ca}$ (Horst et al., 1997) and increase intestinal Ca absorption (Lomba et al., 1978). Tissue responsiveness to PTH was postulated to increase with greater blood acidity (Goff et al., 1991; Horst et al., 1997). Because anionic salts lead to greater Ca resorption from bone and improved reabsorption via the kidney and gut, it has been hypothesized that an acidogenic ration should 
be accompanied by increased dietary $\mathrm{Ca}$ supplementation to replenish mobilized $\mathrm{Ca}$.

Hypocalcemia was prevented when moderate $\mathrm{Ca}$ (1.16\% of DM) was included in anionic diets (Oetzel et al., 1988). In a study with prepartum cows, dietary Ca was increased $(0.44,0.97$, and $1.5 \%$ of $\mathrm{DM})$ as DCAD was decreased $(+15,0$, and $-15 \mathrm{mEq} / 100 \mathrm{~kg}$ of feed DM; Moore et al., 2000). The rationale was that increased urinary Ca losses would be compensated by higher dietary Ca. Although reducing DCAD did improve blood ionized Ca levels at calving, dietary $\mathrm{Ca}$ concentrations were not compared across DCAD treatments and efficacy of dietary Ca content across DCAD could not be determined. Field recommendations for dietary Ca concentrations greater than $1.5 \%$ in negative DCAD diets are common, yet there are limited data to support the recommendation, and the most efficacious prepartum dietary $\mathrm{Ca}$ concentration remains subject to speculation. The objectives of this trial were to determine the effects of feeding a moderate or high prepartum dietary Ca concentration in the presence of anionic salts on DMI and blood and urinary metabolites from d 21 prepartum through $\mathrm{d} 21$ postpartum and on milk yield and milk composition from d 0 through d 21 postpartum.

\section{MATERIALS AND METHODS}

\section{Experimental Design}

Twenty-one Holstein heifers and cows were trained to operate electronic gate feeders (American Calan, Northwood, $\mathrm{NH}$ ) for approximately $10 \mathrm{~d}$ before the final $3 \mathrm{wk}$ prepartum. Cattle were housed in a free-stall barn with a metal roof, 4.3-m eaves, and open ridge vent, had free access to individual free stalls, and were cooled with fans fitted with a high-pressure misting system. Cattle were offered a TMR once daily $(0800 \mathrm{~h})$ that was pushed up to cows frequently to provide for ad libitum consumption and approximately $10 \%$ orts. The TMR was mixed using a mechanized feeder (American Calan) and orts were removed and weighed daily. Table 1 displays the components and nutrient composition of experimental rations. Following calving, cows were fed a TMR with a positive DCAD and 1.0\% Ca (dry basis) (Chan et al., 2005). Cows were milked twice daily at approximately 0400 and 1500 $\mathrm{h}$, and milk yield was measured at each milking from day of calving through $21 \mathrm{~d}$ postpartum. Health-related incidents were recorded, and cows were treated according to symptoms.

The trial consisted of a 21 -d prepartum phase followed by a 21-d postpartum phase and was conducted at the University of Georgia Dairy Research Center in Tifton from August 10 to November 16. Nine nonlactating, pregnant cows paired according to previous lactation 305-d mature equivalent milk yield, and 12 prepartum
Table 1. Composition of treatment diets

\begin{tabular}{|c|c|c|}
\hline & \multicolumn{2}{|c|}{ Dietary $\mathrm{Ca}$ treatment } \\
\hline & $\begin{array}{l}0.99 \% \\
\mathrm{Ca}\end{array}$ & $\begin{array}{l}1.50 \% \\
\mathrm{Ca}\end{array}$ \\
\hline \multicolumn{3}{|l|}{ Ingredient (\% DM) } \\
\hline Corn silage & 47.1 & 47.1 \\
\hline Alfalfa hay & 14.7 & 14.7 \\
\hline Cottonseed & 5.6 & 5.6 \\
\hline Steam-flaked corn & 16.9 & 15.1 \\
\hline Soybean meal (48\% CP) & 5.5 & 5.5 \\
\hline Biochlor $^{1}$ & 10.2 & 10.2 \\
\hline Calcium carbonate & 0.0 & 1.8 \\
\hline \multicolumn{3}{|l|}{ Chemical composition } \\
\hline $\mathrm{CP}$ & 13.9 & 13.2 \\
\hline Undegradable protein, $\%$ of $\mathrm{CP}^{2}$ & 38.9 & 38.8 \\
\hline $\mathrm{NE}_{\mathrm{L}} \mathrm{Mcal} / \mathrm{kg}^{2}$ & 1.7 & 1.6 \\
\hline Ether extract & 3.6 & 3.4 \\
\hline $\mathrm{ADF}$ & 21.2 & 21.3 \\
\hline NDF & 35.1 & 35.4 \\
\hline $\mathrm{NFC}^{2}$ & 36.1 & 34.8 \\
\hline $\mathrm{Ca}$ & 0.99 & 1.50 \\
\hline $\mathrm{P}$ & 0.32 & 0.41 \\
\hline $\mathrm{Mg}$ & 0.24 & 0.26 \\
\hline $\mathrm{K}$ & 1.18 & 1.19 \\
\hline $\mathrm{Na}$ & 0.15 & 0.14 \\
\hline $\mathrm{Cl}$ & 0.61 & 0.61 \\
\hline $\mathrm{S}$ & 0.40 & 0.39 \\
\hline $\mathrm{DCAD}^{3}$ & -6.02 & -5.57 \\
\hline
\end{tabular}

${ }^{1}$ Formerly Biovance Technologies, Inc., Omaha, NE.

${ }^{2}$ Calculated using NRC (2001) values.

${ }^{3} \mathrm{DCAD}$ in $\mathrm{mEq}(\mathrm{Na}+\mathrm{K}-\mathrm{Cl}-\mathrm{S})$ per $100 \mathrm{~g}$ of $\mathrm{DM}$.

heifers paired according to PTA were assigned randomly to either moderate dietary $\mathrm{Ca}(0.99 \%$ of $\mathrm{DM})$ or high dietary $\mathrm{Ca}(1.50 \%$ of $\mathrm{DM})$ treatment at $21 \mathrm{~d}$ prepartum. These treatments were equivalent to 109 and $165 \mathrm{~g}$ of Ca/ cow per d based on $11 \mathrm{~kg} / \mathrm{d}$ of DMI. Cows were sampled on $\mathrm{d} 21$ to 1 prepartum (PRE), d 0 to 2 postpartum (CALVING), and d 3 to 21 postpartum (POST). Treatments were formulated to contain a DCAD of $-6.43 \mathrm{mEq}$ $(\mathrm{Na}+\mathrm{K}-\mathrm{Cl}-\mathrm{S}) / 100 \mathrm{~g}$ of DM using Biochlor (formerly Biovance Technologies, Inc., Omaha, NE, now Church and Dwight, Princeton, NJ) as an anionic salt source. Experimental protocols were approved by the University of Georgia Institutional Animal Care and Use Committee.

\section{Sampling}

Samples of feed ingredients and experimental diets were collected weekly. Samples were dried in a forcedair oven at $60^{\circ} \mathrm{C}$ for $72 \mathrm{~h}$ to determine DM percentage; TMR DM percentage was used to calculate daily DMI. Dried feed samples were ground to pass through a 6-mm screen using a Wiley mill (Arthur Thomas, Philadelphia, PA) and stored in cool, dry conditions. Weekly feed samples were composited for 3-wk intervals, ground to pass through a 1-mm screen using a Wiley mill, and stored 
for later analysis. Weekly milk samples were collected from 2 consecutive milkings for 3 wk postpartum.

Blood was obtained by jugular venipuncture using evacuated tubes and urine was collected by manual stimulation. Blood and urine were collected at approximately $4 \mathrm{~h}$ postfeeding. Blood and urinary samples were collected once before implementing dietary treatments (baseline), approximately $3 \mathrm{wk}$ prepartum, twice during the second week prepartum, and twice during the final week prepartum at approximately $1400 \mathrm{~h}$ each day. Blood and urinary samples were also collected on the day of calving, first day postpartum, second day postpartum, and once each week postpartum for 3 wk.

\section{Analyses}

Milk samples were analyzed at the Southeast DHIA Laboratory (McDonough, GA) for fat and protein content using infrared analysis (Multispec, Foss Electric, Hillerød, Denmark). Blood and urinary samples were analyzed immediately after collection by the University of Georgia Veterinary Diagnostic Laboratory (Tifton) for $\mathrm{Na}, \mathrm{K}, \mathrm{Cl}, \mathrm{Ca}, \mathrm{P}, \mathrm{Mg}$, and $\mathrm{HCO}_{3}^{-}$(Roche-Hitachi 912, Hoffmann-La Roche, Inc., Indianapolis, IN). Serum and urinary cation-anion difference $(\mathbf{C A D})$ were calculated using the equation $\mathrm{mEq}(\mathrm{Na}+\mathrm{K}-\mathrm{Cl}) / \mathrm{L}$. Urinary $\mathrm{pH}$ was also determined ( $\mathrm{pH}$ meter-340, Corning, Inc., Corning, NY).

Dry matter content of feeds was determined (AOAC, 1984). Feed N and S were measured (Leco Corporation, St. Joseph, MI), and CP was calculated as percentage of $\mathrm{N} \times 6.25$. Acid detergent fiber and NDF were determined by the method of Goering and Van Soest (1970). Sodium, $\mathrm{K}, \mathrm{Ca}$, and $\mathrm{Mg}$ were measured by atomic absorption spectrophotometry (model no. 3030, Perkin-Elmer, Norwalk, CT) following acid digestion. Phosphorus was determined colorimetrically using a Beckman DU-60 spectrophotometer (Beckman Instruments, Inc., Fullerton, CA) following acid digestion. Chloride was extracted with a combination of acetic acid and nitric acid and was determined by the method of Cotlove et al. (1958) using a chloridometer (Haake Buchler Instruments, Inc., Saddle Brook, NJ). Fat content of feeds and TMR was determined by ether extraction (Soxtec System HT6, Tecator, Hoganas, Sweden).

\section{Statistical Analyses}

Data were analyzed using the Proc MIXED procedure (SAS Institute, 1999). An ANOVA was conducted for a replicated randomized block design with 2 treatments. The model was

$$
\begin{aligned}
\mathrm{Y}_{\mathrm{ijk}}= & \mu+\operatorname{trt}_{\mathrm{i}}+\operatorname{per}_{\mathrm{j}}+\operatorname{par}_{\mathrm{k}}+\left(\operatorname{trt}_{\mathrm{i}} \times \operatorname{per}_{\mathrm{j}}\right)+\left(\operatorname{per}_{\mathrm{j}} \times \operatorname{par}_{\mathrm{k}}\right) \\
& +\left(\operatorname{trt}_{\mathrm{i}} \times \operatorname{par}_{\mathrm{k}}\right)+\left(\operatorname{trt}_{\mathrm{i}} \times \operatorname{per}_{\mathrm{j}} \times \operatorname{par}_{\mathrm{k}}\right)+\Sigma_{\mathrm{ijk}}
\end{aligned}
$$

where $\mu=$ the mean intercept, $\operatorname{trt}_{i}=$ the effect due to treatment $i, \operatorname{per}_{j}=$ the effect due to period $j, \operatorname{par}_{k}=$ the effect due to parity k, 2- and 3-way interactions, and $\Sigma=$ error associated with each $\mathrm{Y}_{\mathrm{ijk}}$.

Significance was declared at $P<0.05$ unless stated otherwise, using the $F$-test of significance. Preliminary analyses revealed no interactions of dietary treatment by day of study or dietary treatment by week of study $(P>0.20)$ so the final model including period was used for reporting results. Regression analyses were conducted and correlation coefficients determined according to the Proc REG and Proc CORR (SAS Institute, 1999) procedures.

\section{RESULTS AND DISCUSSION}

\section{Serum and Urinary Electrolytes}

Serum Ca concentration was not different among treatments (Table 2 and Figure 1). Lack of treatment effect agrees with Oetzel et al. (1988), who determined that $\mathrm{DCAD}$, not dietary $\mathrm{Ca}$, is implicated in incidence of milk fever. The DCAD for treatments was similar (Table 1) and comparable serum Ca concentrations were maintained. In studies with sheep, dietary Ca content had no effect on plasma Ca concentration and apparent absorption of $\mathrm{Ca}$ was not different for diets containing 0.47 or $0.82 \% \mathrm{Ca}$ (Takagi and Block, 1991). In the present study, dietary Ca concentrations were 0.99 and $1.50 \%$ Ca.

There was no incidence of hypocalcemia, as serum Ca never fell below the $8 \mathrm{mg} / \mathrm{dL}$ (Figure 1) deemed necessary to indicate hypocalcemia (Mayer et al., 1969). Serum Ca was maintained at an adequate level during both prepartum and postpartum periods (Figure 1) for both moderate and high Ca diets. Serum Ca reached its nadir during the calving period or $1 \mathrm{~d}$ after parturition (Figure 1), similar to previous reports (Romo et al., 1991; Abu Damir et al., 1994). Two cases of retained placenta occurred in cows receiving the $0.99 \%$ Ca treatment. These cows had low DMI at parturition, which was probably not related to treatment. Higher blood Ca concentrations were reported for cows fed anionic diets (Block, 1984; Joyce et al., 1997). Acidogenic diets are hypothesized to increase serum $\mathrm{Ca}$ by increasing Ca mobilization from bone as indicated by elevated serum hydroxyproline (Goff et al., 1991) and decreasing Ca reabsorption via the kidney tubules leading to bone Ca release as a means to maintain blood Ca (Van Mosel et al., 1994), mediated through increased serum PTH concentration (Horst et al., 1997). Greater dietary acidity increases the efficiency 
Table 2. Serum and urinary electrolyte concentrations for prepartum cows offered anionic diets containing 0.99 or $1.50 \% \mathrm{Ca}$

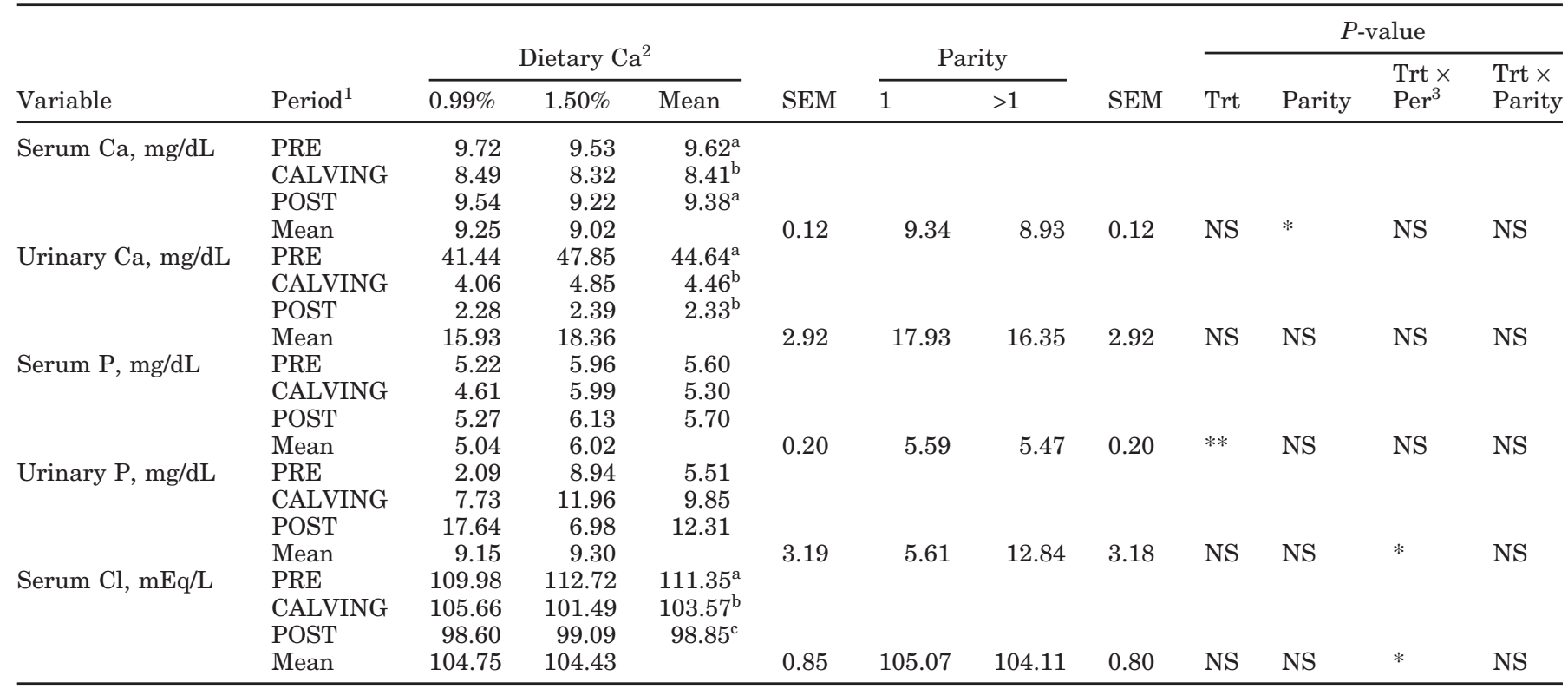

${ }^{a-c}$ Means within column for each variable with different superscripts are different $(P<0.05)$.

${ }^{1}$ Periods PRE, CALVING, and POST represent d 21 to 1 prepartum, d 0 to 2 postpartum, and d 3 to 21 postpartum, respectively.

${ }^{2}$ Trt $=$ Treatment: $0.99 \%$ and $1.50 \%$ dietary Ca.

${ }^{3}$ Per $=$ Period.

$* P<0.05 ; * * P<0.01$.

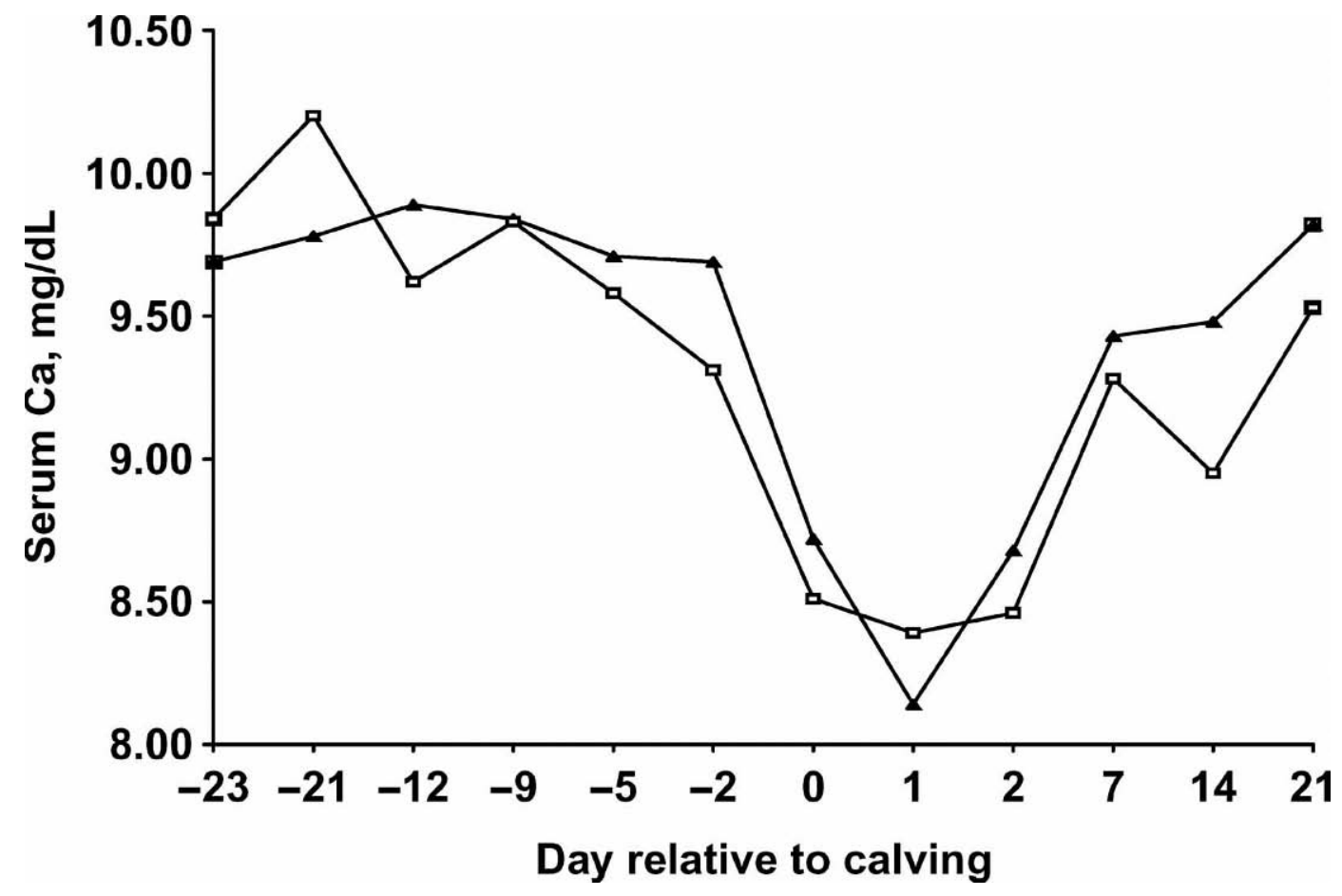

Figure 1. Serum Ca concentration for cows offered an anionic diet containing either $0.99 \%(\mathbf{\Lambda})$ or $1.50 \%$ dietary Ca ( $\square)$. Day -23 represents baseline serum Ca. 


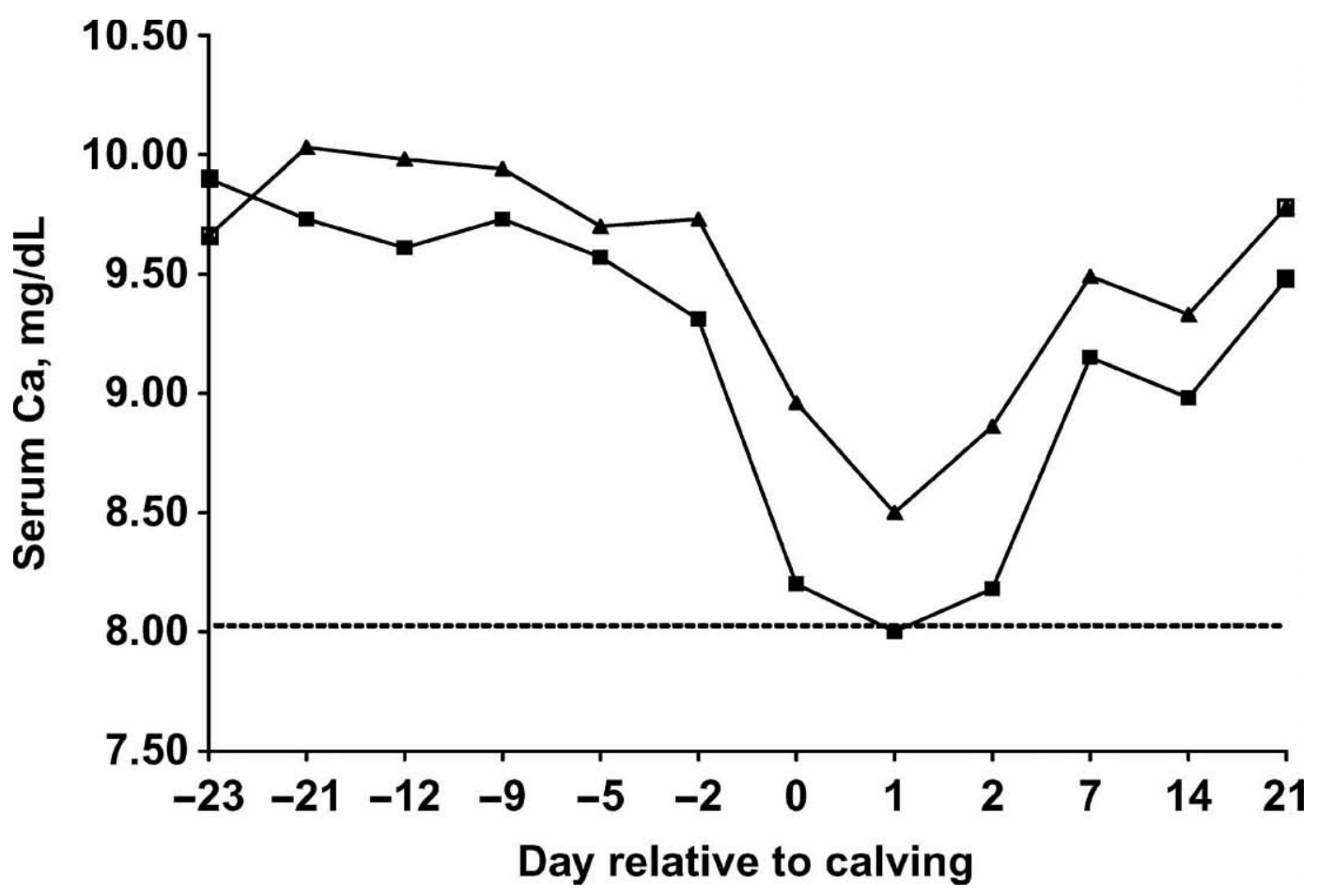

Figure 2. Serum Ca concentration for primiparous ( $\mathbf{\Delta})$ and multiparous ( $\mathbf{\square})$ cows offered an anionic diet containing either 0.99 or $1.50 \%$ dietary Ca. Day -23 represents baseline serum Ca.

of Ca absorption from the gastrointestinal tract (Lomba et al., 1978). The exact mechanism by which Ca metabolism is altered in the present study cannot be established without assessment of a bone resorption indicator such as serum hydroxyproline or a gastrointestinal absorption and kidney reabsorption indicator such as serum 1,25-hydroxycholecalciferol.

Primiparous cows had higher $(P=0.02)$ serum Ca concentrations than mature cows throughout the study period (Figure 2) and averaged 9.34 and $8.93 \mathrm{mg} / \mathrm{dL}$, respectively (Table 2). This is in agreement with previous reports (Van Mosel et al., 1994; Moore et al., 2000). Serum Ca concentration for multiparous cows approached $8 \mathrm{mg} / \mathrm{dL}$ around parturition (Figure 2). Primiparous cows exhibit a low incidence of hypocalcemia when compared with mature cows (Shappell et al., 1987) because of lower milk yield and the ability to readily mobilize Ca stores. The ongoing growth process in heifers allows easier bone Ca resorption as the maximum stability of the skeletal structure has not been reached, and there is probably greater bone turnover in younger animals (Van Mosel et al., 1994). If blood Ca concentrations are maintained near normal in heifers, anionic salts may not be required. Moore et al. (2000) reported depressed feed intake for heifers when supplemented with anionic salts.

There was no treatment effect for urinary Ca but urinary $\mathrm{Ca}$ concentration was numerically greater for the
1.50\% Ca diet for all periods (Table 2). Others (Block, 1984; Oetzel et al., 1988; Goff et al., 1991; Romo et al., 1991) reported lower milk fever incidence with acidogenic diets containing 86,105, 106, and $102 \mathrm{~g} / \mathrm{d}$ of $\mathrm{Ca}$, respectively, compared with cationic diets. Based on 11 $\mathrm{kg} / \mathrm{d}$ of DMI, the $0.99 \%$ and $1.50 \%$ dietary Ca diets provided a daily $\mathrm{Ca}$ intake of 109 and $165 \mathrm{~g} / \mathrm{d}$ in the present trial. Absence of a dietary Ca effect on urinary Ca was observed by Oetzel et al. (1991) for anionic diets containing 0.84 or $1.18 \% \mathrm{Ca}$.

Urinary $\mathrm{Ca}$ for both treatments decreased $(P<0.05)$ from $44.64 \mathrm{mg} / \mathrm{dL}$ at PRE to $2.33 \mathrm{mg} / \mathrm{dl}$ at POST. Higher urinary $\mathrm{Ca}$ at PRE reflects the effects of anionic salts in mobilizing $\mathrm{Ca}$ and indicates that a surplus of dietary $\mathrm{Ca}$ was present. In addition, Ca demand by the prepartum cow is relatively low. Lower urinary Ca after parturition results from increased demand for Ca by the mammary gland for milk synthesis and an alkaline or positive $\mathrm{DCAD}$ diet. Alkaline diets also reduce $\mathrm{Ca}$ bone resorption (Block, 1984) and intestinal absorption (Lomba et al., 1978). The body is very likely conserving $\mathrm{Ca}$ for milk production as reflected by reduced urinary $\mathrm{Ca}$ excretion. Infusing EDTA to stimulate a surge in Ca demand at calving causes urinary Ca to decline to near zero (Schonewille et al., 1999). Thus, the reduced urinary Ca excretion from PRE to POST was probably a result of higher 
physiological $\mathrm{pH}$, lactation demand for $\mathrm{Ca}$, and changing diet.

Serum $P$ concentration was higher $(P<0.05)$ for cows offered the $1.50 \%$ Ca diet compared with those offered the $0.99 \%$ Ca diet (Table 2). Serum $\mathrm{P}$ is closely related to serum $\mathrm{Ca}$ because both make up the hydroxyapatite lattice structure of bone. Because serum Ca did not differ with treatment, serum $\mathrm{P}$ is expected to respond likewise. However, the greater dietary $\mathrm{P}$ concentration for the 1.5\% Ca diet may have contributed to the higher serum $\mathrm{P}$ concentration because $\mathrm{P}$ is absorbed in relation to $\mathrm{P}$ intake (Reinhardt et al., 1988). Serum P concentration tended to be higher for primiparous cows compared with mature cows (Table 2), similar to reports by Romo et al. (1991). There was no difference in serum $P$ as cows transitioned from PRE to POST in the present study (Table 2). No treatment effects or interactions $(P>0.10)$ were observed for serum and urinary $\mathrm{Mg}, \mathrm{Na}$, and $\mathrm{K}$ (data not shown).

At CALVING, serum $\mathrm{Cl}$ concentration was greater for the $0.99 \% \mathrm{Ca}$ treatment $(P<0.05$; Table 2$)$. In calves, plasma $\mathrm{Cl}$ was higher with lower dietary Ca content (Jackson and Hemken, 1994). On the day of parturition, the body depends largely on mobilized Ca. The body conserves chloride, increasing systemic acidity, which improves bone Ca resorption (Block, 1984; Goff et al., 1991), and Ca absorption from the intestine (Goff et al., 1991; Phillippo et al., 1994). Increased tissue responsiveness to PTH occurs (Horst et al., 1997) as the metabolic alkalosis becomes a metabolic acidosis in response to the low DCAD. The result is more efficient intestinal absorption of $\mathrm{Ca}$, improved bone resorption, and greater retention of $\mathrm{Ca}$ within the body. A positive linear relationship between serum $\mathrm{Ca}$ and serum $\mathrm{Cl}$ was found $(\mathrm{r}=$ $0.41, P<0.0001)$ at CALVING. Dietary $\mathrm{Cl}$ during PRE was increased by supplementation with the anionic salt supplement. Block (1984) reported that plasma $\mathrm{Cl}$ increased with $\mathrm{Cl}$ content in the diet. Serum $\mathrm{Cl}$ decreased significantly from PRE to POST because of reduced dietary $\mathrm{Cl}$ (Tables 1 and 2).

\section{Serum and Urinary Acid-Base Chemistry}

The benefits of supplementing anionic salts prepartum may be mediated through a disturbance of systemic acid-base chemistry. Serum $\mathrm{HCO}_{3}{ }^{-}$(Table 3 ) was below the normal concentration of 21.5 to $27.7 \mathrm{mEq} / \mathrm{L}$ (Benjamin, 1981) during PRE because a mild metabolic acidosis was induced by the anionic diet. Higher serum $\mathrm{Cl}$ concentration (Table 2) during PRE was accompanied by lower serum $\mathrm{HCO}_{3}^{-}$, urinary $\mathrm{HCO}_{3}^{-}$, and urinary $\mathrm{pH}$ (Table 3 ). Thus, serum $\mathrm{pH}$ would be expected to decrease with an anionic diet. Abu Damir et al. (1994) reported lower blood $\mathrm{pH}$ when acidogenic diets were fed to cows. Ele- vated serum $\mathrm{Cl}$ requires hydrogen ions to maintain electroneutrality and increasing hydrogen ion concentration reduces blood $\mathrm{pH}$. In prepartum cows, elevated plasma $\mathrm{Cl}$ was accompanied by lower blood $\mathrm{pH}$ (Phillippo et al., 1994). Blood $\mathrm{HCO}_{3}{ }^{-}$was inversely related to blood hydrogen ion concentration and both blood $\mathrm{HCO}_{3}{ }^{-}$and urinary $\mathrm{pH}$ were reduced when $\mathrm{Cl}$ intake increased (Tucker et al., 1992).

The absence of treatment effect for both serum and urinary $\mathrm{HCO}_{3}^{-}$in the present study was anticipated because of similarity in dietary anion content. At baseline, urinary $\mathrm{pH}$ was similar for both treatments (Figure 3). Urinary $\mathrm{HCO}_{3}{ }^{-}$was low and coincided with the low urinary $\mathrm{pH}$ and low serum $\mathrm{HCO}_{3}{ }^{-}$(Table 3), reflecting the metabolic acidosis induced during PRE by the presence of dietary anionic salts. Urinary $\mathrm{HCO}_{3}{ }^{-}$and $\mathrm{pH}$ exhibited period effects $(P<0.05$; Table 3$)$; both increased with the alkaline DCAD postcalving. Reduced urinary $\mathrm{pH}$ accompanied by a decline in urinary $\mathrm{HCO}_{3}^{-}$was also observed by Schonewille et al. (1999). A mild metabolic acidosis is expected to be induced by anionic salts (Joyce et al., 1997) and successful implementation of anionic salts in the late-gestation cow is indicated by urinary $\mathrm{pH}$ between 5.5 to 6.5 , achieved in the present trial (Table 3). The compensated metabolic acidosis and shortlived effects of anionic salts reported previously by Tucker et al. (1992) were found in the present trial where urinary $\mathrm{pH}$ changed within a day following alteration of DCAD (Figure 3).

Serum CAD was lower at PRE compared with that during CALVING and POST (Table 3), consistent with the negative DCAD diet that was fed. Serum CAD was positively correlated with serum $\mathrm{HCO}_{3}{ }^{-}(\mathrm{r}=0.78 ; P<$ 0.0001) throughout the entire study period. Figure 4 shows the positive relationship between serum $\mathrm{HCO}_{3}{ }^{-}$ and serum CAD at CALVING. An anionic diet leads to low serum $\mathrm{HCO}_{3}^{-}$, causing perturbations to systemic acid-base balance and leading to the desired effects on Ca metabolism. Serum CAD can be a good indicator of systemic acid-base chemistry and could be used to monitor the effectiveness of anionic salts in inducing a mild metabolic acidosis. Urinary CAD (Table 3) followed a pattern similar to serum $\mathrm{CAD}$, with the transition from PRE to POST reflecting the change from negative to positive $\mathrm{DCAD}$ in the diet. The serum $\mathrm{CAD}$ values were in a more narrow range than urinary $\mathrm{CAD}$ because the body regulates serum contents very closely to ensure homeostasis, whereas excretion occurs through the kidneys.

\section{Intake}

No differences were observed for DMI among treatments although there was a numerical advantage for 
Table 3. Serum and urinary acid-base chemistry concentrations for cows offered anionic diets containing either 0.99 or $1.50 \%$ dietary Ca prepartum

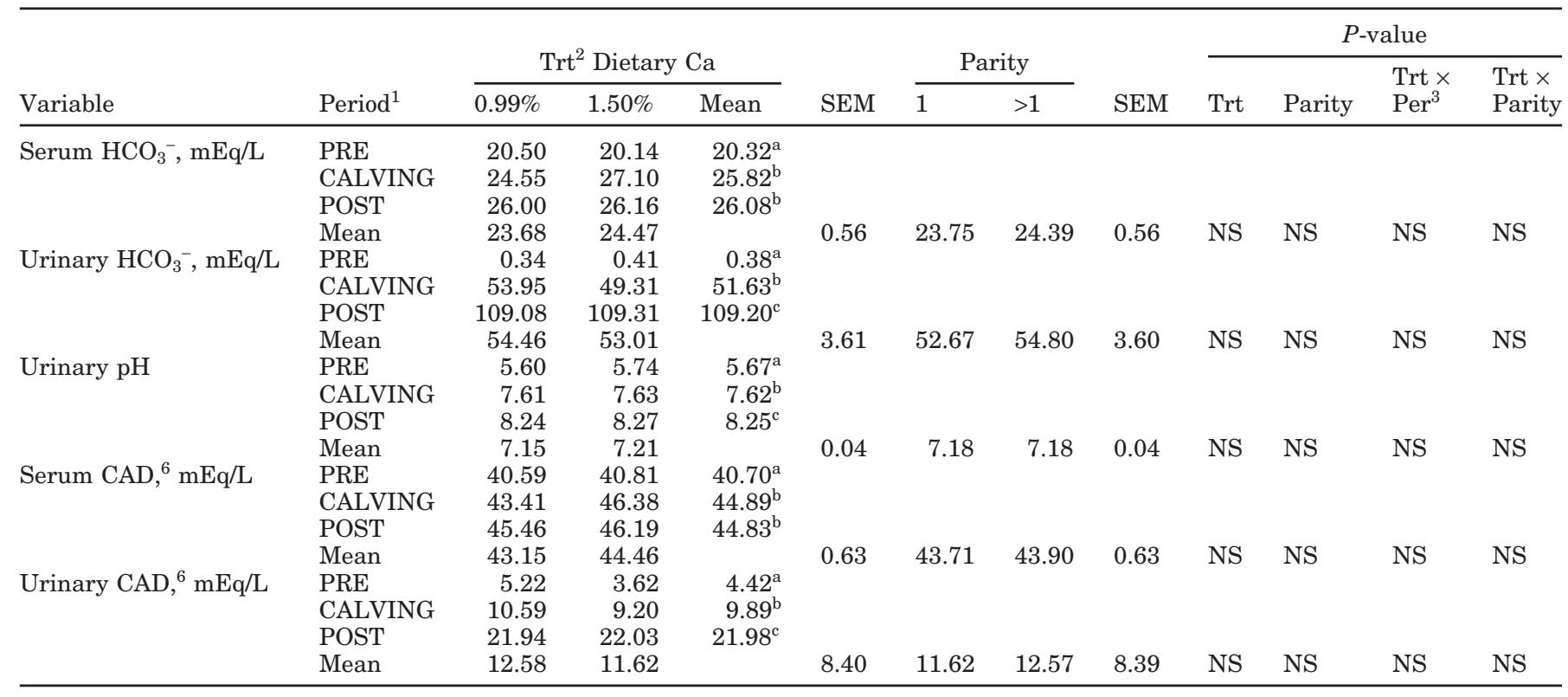

${ }^{\mathrm{a}-\mathrm{c}}$ Means within column for each variable with different superscripts are different $(P<0.05)$.

${ }^{1}$ Periods PRE, CALVING, and POST represent d 21 to 1 prepartum, d 0 to 2 postpartum, and d 3 to 21 postpartum, respectively.

${ }^{2}$ Trt $=$ Treatment; $0.99 \%$ and $1.50 \%$ dietary $\mathrm{Ca}$.

${ }^{3}$ Per $=$ Period.

${ }^{5} \mathrm{CAD}=$ Cation-anion difference calculated from the equation: $(\mathrm{Na}+\mathrm{K}-\mathrm{Cl}) \mathrm{mEq} / \mathrm{L}$.

the $0.99 \%$ Ca diet (Table 4). Intake was not affected by increasing dietary Ca content in diets for calves (Jackson and Hemken, 1994), cows (Oetzel et al., 1988), or sheep
(Takagi and Block, 1991). Multiparous cows consumed more DM $(P<0.05)$ both prepartum and postpartum than primiparous cows, in agreement with previous re-

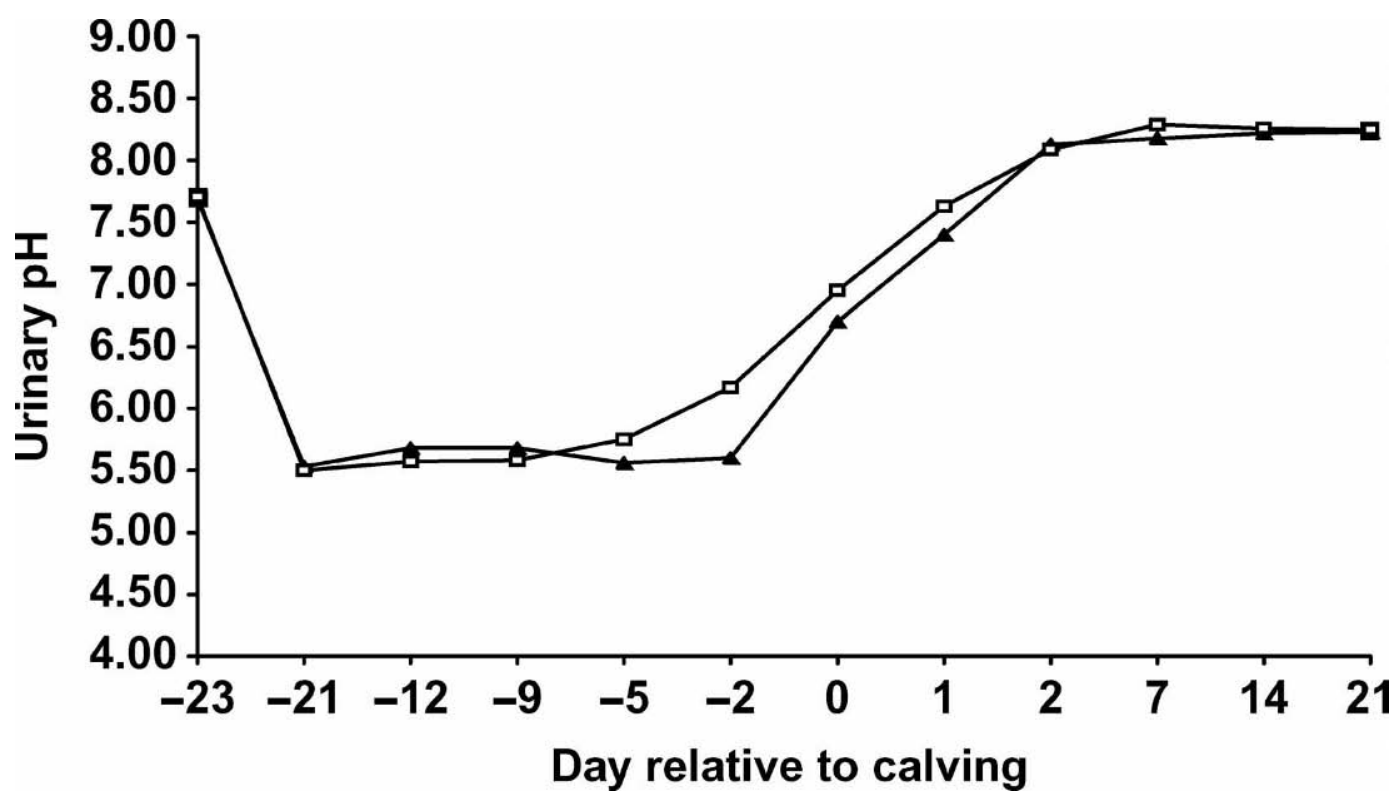

Figure 3. Urinary $\mathrm{pH}$ for cows offered an anionic diet containing either $0.99 \%(\boldsymbol{\Delta})$ or $1.50 \%$ dietary Ca ( $\square)$. Day -23 represents baseline urinary $\mathrm{pH}$ 


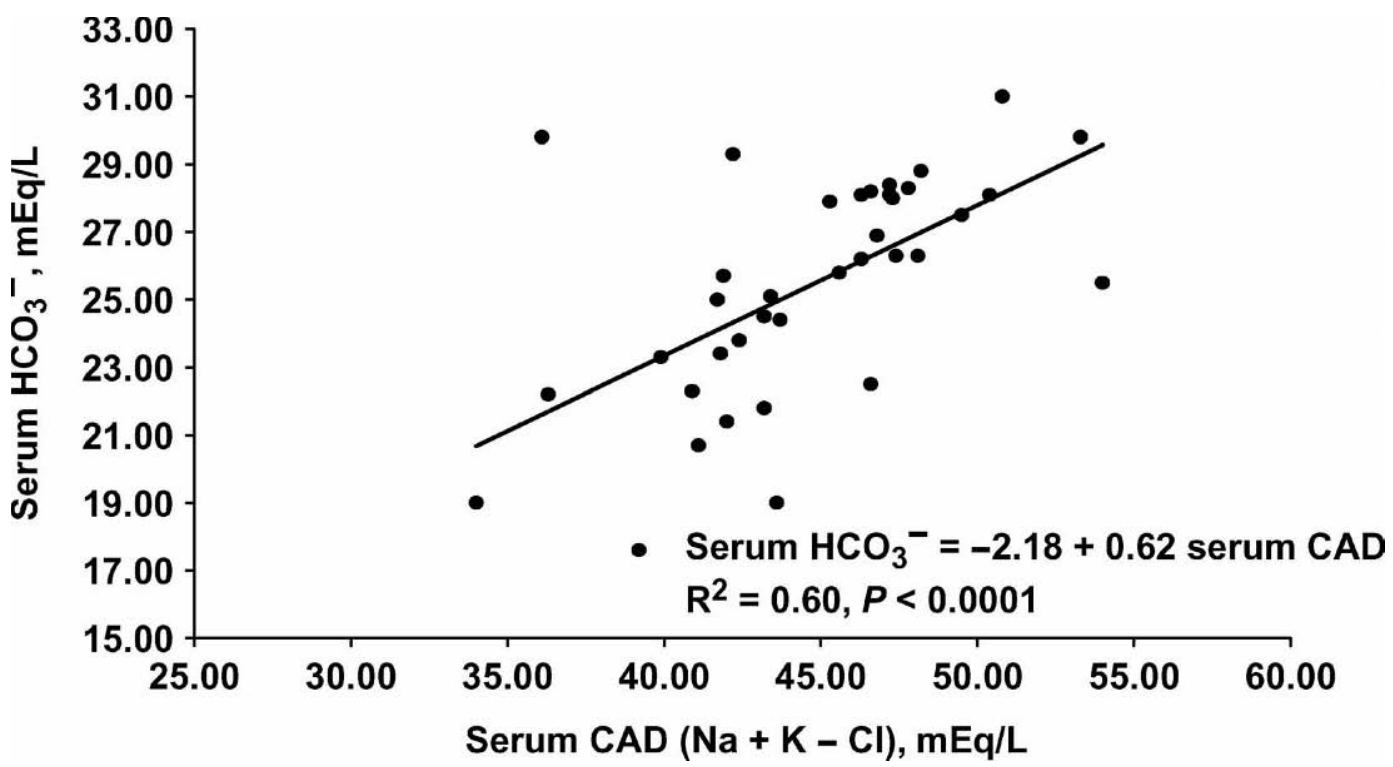

Figure 4. Simple linear regression of serum $\mathrm{HCO}_{3}{ }^{-}$on serum cation-anion difference $[\mathrm{CAD} ;(\mathrm{Na}+\mathrm{K}-\mathrm{Cl}) \mathrm{mEq} / \mathrm{L}]$ from d 0 , 1 , and 2 postpartum for cows offered anionic diets prepartum.

ports (Kertz et al., 1991; Moore et al., 2000). However, intake per unit of BW was similar for primiparous and multiparous cows (Table 4).

Figure 5 displays mean DMI by treatment from $21 \mathrm{~d}$ prepartum to $21 \mathrm{~d}$ postpartum. There was about a $30 \%$ decrease in DMI during the last week prepartum, in agreement with Bertics et al. (1992). Regression analysis of DMI on day prepartum for the present study revealed a $0.97 \mathrm{~kg} / \mathrm{d}$ decrease in DMI for the week preceding parturition. Dry matter intake increased by $0.34 \mathrm{~kg} / \mathrm{d}$ for wk 1 through wk 3 postpartum. Both models were highly significant $(P<0.0001)$ although low $\mathrm{R}^{2}(0.20$ and 0.21 for prepartum and postpartum data) were obtained because of variation that occurred between cows (ex-

Table 4. Intake, milk yield, and milk composition for cows offered anionic diets prepartum containing 0.99 or $1.50 \%$ Ca.

\begin{tabular}{|c|c|c|c|c|c|c|c|c|c|}
\hline \multirow[b]{2}{*}{ Variable } & \multirow{2}{*}{$\begin{array}{l}\text { Dietary } \\
\mathrm{Ca}\end{array}$} & \multicolumn{2}{|c|}{ Dietary Ca effects } & \multicolumn{3}{|c|}{ Parity effects } & \multirow[b]{2}{*}{ SEM } & \multicolumn{2}{|c|}{$P$-value ${ }^{5}$} \\
\hline & & Prepartum $^{1}$ & Postpartum $^{2}$ & Parity & Prepartum $^{3}$ & Postpartum $^{4}$ & & Trt & Parity \\
\hline DMI, kg/d & $0.99 \%$ & 11.8 & 14.6 & 1 & 10.4 & 13.2 & 0.9 & NS & $*$ \\
\hline \multirow[t]{2}{*}{ DMI, kg/100 kg BW } & $0.99 \%$ & 2.01 & 2.80 & 1 & 1.95 & 2.86 & \multirow[t]{2}{*}{0.20} & \multirow[t]{2}{*}{ NS } & \multirow[t]{2}{*}{ NS } \\
\hline & $1.50 \%$ & 1.91 & 2.72 & $>1$ & 1.88 & 2.69 & & & \\
\hline \multirow{2}{*}{ Milk, $\mathrm{kg} / \mathrm{d}$} & $0.99 \%$ & & 22.8 & 1 & & 19.1 & \multirow[t]{2}{*}{1.8} & \multirow[t]{2}{*}{ NS } & \multirow[t]{2}{*}{$*$} \\
\hline & $1.50 \%$ & & 20.7 & $>1$ & & 24.4 & & & \\
\hline \multirow[t]{2}{*}{ Fat, \% } & $0.99 \%$ & & 4.17 & 1 & & 4.27 & \multirow[t]{2}{*}{0.18} & \multirow[t]{2}{*}{ NS } & \multirow[t]{2}{*}{$*$} \\
\hline & $1.50 \%$ & & 3.83 & $>1$ & & 3.73 & & & \\
\hline \multirow[t]{2}{*}{ Protein, \% } & $0.99 \%$ & & 3.22 & 1 & & 3.13 & \multirow[t]{2}{*}{0.07} & \multirow[t]{2}{*}{ NS } & \multirow[t]{2}{*}{ NS } \\
\hline & $1.50 \%$ & & 3.14 & $>1$ & & 3.23 & & & \\
\hline \multirow[t]{2}{*}{ Fat, kg/d } & $0.99 \%$ & & 1.03 & 1 & & 0.91 & \multirow[t]{2}{*}{0.09} & \multirow[t]{2}{*}{ NS } & \multirow[t]{2}{*}{ NS } \\
\hline & $1.50 \%$ & & 0.91 & $>1$ & & 1.02 & & & \\
\hline Protein, kg/d & $0.99 \%$ & & 0.80 & 1 & & 0.66 & 0.04 & NS & $*$ \\
\hline
\end{tabular}

${ }^{1}$ Represents treatment mean for each variable from d 21 to 1 prepartum.

${ }^{2}$ Represents treatment mean for each variable from d 0 to 21 postpartum.

${ }^{3}$ Represents parity mean for each variable from d 21 to 1 prepartum.

${ }^{4}$ Represents parity mean for each variable from $\mathrm{d} 0$ to 21 postpartum.

${ }^{5} \mathrm{P}$-value for treatment and parity mean comparison.

$* P<0.05$ 


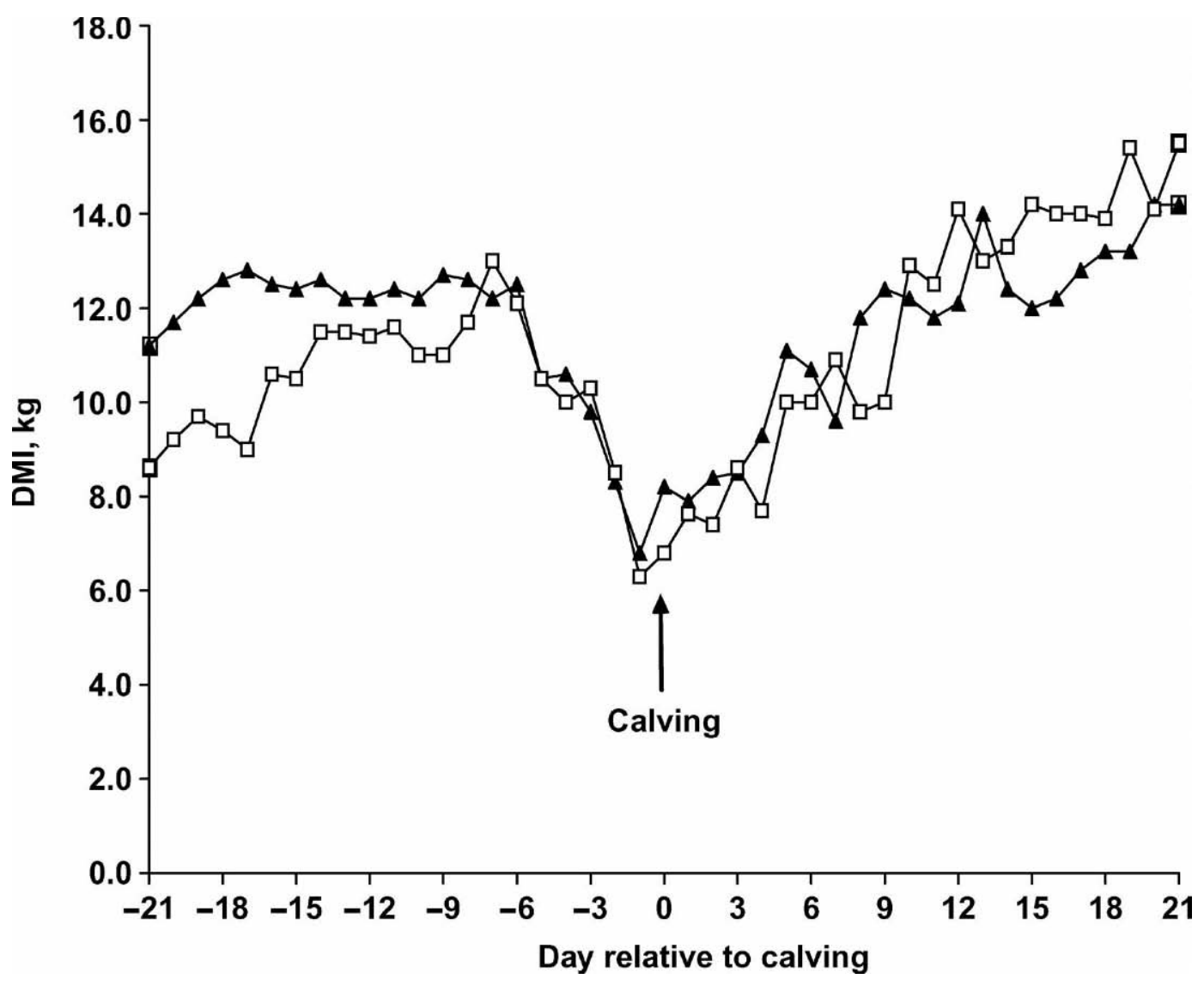

Figure 5. Daily prepartum and postpartum DMI for cows offered anionic diets containing either $0.99 \%(\mathbf{\Delta})$ or $1.50 \%$ dietary Ca ( $\square$ ).

pected at this stressful transition period). The correlation coefficient between DMI at $4 \mathrm{~d}$ prepartum and 21 d postpartum was $0.55(P<0.01)$, indicating that postpartum DMI is closely related to prepartum DMI, in agreement with the results of Grummer (1995). However, 3 cows fed $1.50 \%$ Ca exhibited low DMI throughout the study period, resulting in depressed DMI from d 21 to 7 prepartum.

\section{Milk Yield and Composition}

No differences were observed for milk yield or yield and concentration of milk fat and protein (Table 4). Multiparous cows yielded $5.3 \mathrm{~kg} / \mathrm{d}$ more milk $(P<0.05)$ than primiparous cows. Yield of milk fat was numerically higher and yield of protein was significantly greater for the multiparous cows, due primarily to greater milk yield. Similar differences were reported by Tucker et al. (1992). Milk production is limited by DMI (Kertz et al., 1991), and in this study, a positive linear correlation was found between the 2 variables $(\mathrm{r}=0.55, P<0.0001)$. The lack of a greater correlation is probably related to the use of body fat stores for milk production, reducing the correlation between intake and milk yield.

\section{CONCLUSIONS}

Dietary Ca content of $0.99 \%$ appears to be adequate when feeding an anionic diet with DCAD of $-6 \mathrm{mEq} / 100$ $\mathrm{g}$ of DM to prepartum cows. Serum Ca never declined below $8 \mathrm{mg} / \mathrm{dL}$ throughout the study for both treatments. Feeding anionic diets for $21 \mathrm{~d}$ prepartum was effective in preventing hypocalcemia by inducing a mild metabolic acidosis; reduced urinary $\mathrm{pH}$ reflected the influence of dietary anion content fed. Urinary $\mathrm{pH}$ is a good indicator to monitor implementation of dietary anionic salts and blood CAD can also be a useful measure. Heifers may not benefit from anionic salts because their serum $\mathrm{Ca}$ concentration was maintained at a consistently higher level than for multiparous cows. The absence of an effect of prepartum dietary $\mathrm{Ca}$ on postpartum milk yield and on most serum and urinary metabolites may be attributed to similar DCAD for treatment diets. Anionic diets increased systemic acidity resulting in greater $\mathrm{Ca}$ availability and sustained serum Ca during the critical periparturient period.

\section{ACKNOWLEDGMENTS}

The authors would like to thank Dana Bryan, Cameran Asbell, Sue Trammell, Heath Cross, student work- 
ers, and employees from the University of Georgia Dairy Research Center in Tifton for assistance in feeding and caring for cows. Gratitude also goes to Anita Merrill from the University of Georgia Veterinary Diagnostic Laboratory for blood and urine analyses and Biovance Technologies, Inc., for provision of Biochlor as a source of anionic salts.

\section{REFERENCES}

Abu Damir, H., M. Phillippo, B. H. Thorp, J. S. Milne, L. Dick, and I. M. Nevison. 1994. Effects of dietary acidity on calcium balance and mobilization, bone morphology, and 1,25 dihydroxyvitamin D in prepartal dairy cows. Res. Vet. Sci. 56:310-318.

AOAC. 1984. Official Methods of Analysis. 14th ed. Association of Official Agricultural Chemists, Arlington, VA.

Benjamin, M. M. 1981. Fluid and electrolytes. Pages 177, 213-225 in Outline of Vet Clin. Pathol. Iowa State Univ. Press, Ames.

Bertics, S. J., R. R. Grummer, C. Cadorniga-Valino, and E. E. Stoddard. 1992. Effect of prepartum dry matter intake on liver triglyceride concentration and early lactation. J. Dairy Sci. 75:1914-1922.

Block, E. 1984. Manipulating dietary anions and cations for prepartum dairy cows to reduce incidence of milk fever. J. Dairy Sci. 67:2939-2948

Chan, P. S., J. W. West, J. K. Bernard, and J. M. Fernandez. 2005. The effects of increasing dietary cation-anion difference on dry matter intake, milk yield, and metabolic measures of the lactating dairy cow. J. Dairy Sci. 88:4384-4392.

Cotlove, E. H., H. V. Trantham, and R. L. Bowman. 1958. An instrument and method for automatic, accurate, and sensitive titration of chloride in biological samples. J. Lab. Clin. Med. 51:461-468.

Curtis, C. R., H. N. Erb, C. J. Sniffen, R. D. Smith, P. A. Powers, M. C. Smith, M. E. White, R. B. Hillman, and E. J. Pearson. 1983. Association of parturient hypocalcemia with eight periparturient disorders in Holstein cows. J. Am. Vet. Med. Assoc. 183:559-561.

Goering, H. K., and P. J. Van Soest. 1970. Forage Fiber Analyses (Apparatus, Reagents, Procedures, and Some Applications). Agric. Handbook 379. ARS-USDA, Washington, DC.

Goff, J. P., and R. L. Horst. 1997. Effects of the addition of potassium or sodium, but not calcium, to prepartum rations on milk fever in dairy cows. J. Dairy Sci. 80:176-186.

Goff, J. P., R. L. Horst, F. J. Mueller, J. K. Miller, G. A. Kiess, and H. H. Dowlen. 1991. Addition of chloride to a prepartal diet high in cations increases 1,25-dihydroxyvitamin $\mathrm{D}$ response to hypocalcemia preventing milk fever. J. Dairy Sci. 74:3863-3871.

Goings, R. L., N. L. Jacobson, D. C. Beitz, E. T. Littledike, and K. D. Wiggers. 1974. Prevention of parturient paresis by a prepartum calcium deficient diet. J. Dairy Sci. 57:1184-1188.

Grummer, R. R. 1995. Impact of changes in organic nutrient metabolism on feeding the transition dairy cow. J. Anim. Sci. 73:28202833.

Guard, C. 1996. Fresh cow problems are costly: Culling hurts the most. Page 100 in Proc. Annu. Vet. Conf., Cornell Univ., Ithaca, NY.

Horst, R. L., J. P. Goff, and T. A. Reinhardt. 1997. Pathophysiology and prevention of milk fever in dairy cattle. Pages 21-32 in Proc. IXth Int. Prod. Dis. Farm Anim. Conf., University of Berlin, Germany.
Jackson, J. A., and R. W. Hemken. 1994. Calcium and cation-anion balance effects on feed intake, body weight gain, and humoral response of dairy calves. J. Dairy Sci. 77:1430-1436.

Joyce, P. W., W. K. Sanchez, and J. P. Goff. 1997. Effect of anionic salts in prepartum diets based on alfalfa. J. Dairy Sci. 80:2866-2875.

Kertz, A. F., L. F. Reutzel, and G. M. Thomson. 1991. Dry matter intake from parturition to midlactation. J. Dairy Sci. 74:22902295.

Lomba, F., G. Chauvaux, E. Teller, L. Lengele, and V. Bienfet. 1978. Calcium digestibility in cows as influenced by excess of alkaline ions over stable acid ions in their diets. Br. J. Nutr. 39:425-429.

Mayer, G. P., C. F. Ramberg, and D. S. Kronfeld. 1969. Calcium homeostasis in the cow. Clin. Orthop. 62:79-94.

Moore, S. J., M. J. Vandehaar, B. K. Sharma, T. E. Pilbeam, D. K. Beede, H. F. Bulcholtz, J. S. Liesman, R. L. Horst, and J. P. Goff. 2000. Effects of altering dietary cation-anion difference on calcium and energy metabolism in peripartum cows. J. Dairy Sci. 83:2095-2104.

National Research Council. 2001. Nutrient Requirements of Dairy Cattle. 7th rev. ed. Natl. Acad. Sci., Washington, DC.

Oetzel, G. R., M. J. Fettman, D. W. Hamar, and J. D. Olson. 1991. Screening of anionic salts for palatability, effects on acid-base status, and urinary calcium excretion in dairy cows. J. Dairy Sci. 74:965-971.

Oetzel, G. R., J. D. Olson, C. R. Curtis, M. J. Curtis, and M. J. Fettman. 1988. Ammonium chloride and ammonium sulfate for prevention of parturient paresis in dairy cows. J. Dairy Sci. 71:3302-3309.

Payne, J. M. 1968. Milk fever. Outlook Agric. 5:266-268.

Phillippo, M., G. W. Reid, and I. M. Nevison. 1994. Parturient hypocalcemia in dairy cows: Effects of dietary acidity on plasma minerals and calcitrophic hormones. Res. Vet. Sci. 56:303-309.

Reinhardt, T. A., R. L. Horst, and J. P. Goff. 1988. Calcium, phosphorus, and magnesium homeostasis in ruminants. Vet. Clin. North Am. Food Anim. Pract. 2:331-350.

Romo, G. A., R. O. Kellems, K. Powell, and M. V. Wallentine. 1991. Some blood minerals and hormones in cows fed variable mineral levels and ionic balance. J. Dairy Sci. 74:3068-3077.

SAS Institute. 1999. SAS/STAT User's Guide. Release 8.1. SAS Inst., Inc., Cary, NC.

Schonewille, J. T., A. T. Van't Klooster, H. Wouterse, and A. C. Beynen. 1999. Hypocalcemia induced by intravenous administration of disodium ethylenediaminotetraacetate and its effects on excretion of calcium in urine of cows fed a high chloride diet. J. Dairy Sci. 82:1317-1324.

Shappell, N. W., J. H. Herbein, L. J. Deftos, and R. J. Aiello. 1987. Effects of dietary calcium and age on parathyroid hormone, calcitonin, and serum and milk minerals in the periparturient dairy cow. J. Nutr. 117:201-207.

Takagi, H., and E. Block. 1991. Effects of reducing dietary cation-anion balance on calcium kinetics in sheep. J. Dairy Sci. 74:4225-4237.

Tucker, W. B., J. F. Hogue, G. D. Adams, M. Aslam, I. S. Shin, and G. Morgan. 1992. Influence of dietary cation-anion balance during the dry period on the occurrence of parturient paresis in cows fed excess calcium. J. Anim. Sci. 70:1238-1250.

Vagg, M. J., and J. M. Payne. 1970. The effect of ammonium chloride induced acidosis on calcium metabolism in ruminants. Br. Vet. J. 126:531-537.

Van Mosel, M., H. S. Wouterse, and A. Th. Van't Klooster. 1994. Effects of reducing dietary $\left([\mathrm{Na}++\mathrm{K}+]-\left[\mathrm{Cl}^{-}+\mathrm{SO}_{4}\right]\right)$ on bone in dairy cows at parturition. Res. Vet. Sci. 56:270-276. 